of novelty, and the liking to do as other people are doing, have no doubt exerted in gaining for these "Ladies" Lectures" greater popularity, and a larger share of public attention than they would otherwise have obtained,--we believe that their rapid spread; and the success which has so far attended them, are mainly due to a serious effort on the part of the women of this country to improve their intellectual condition, coupled with the conviction of the inefficiency of the facilities for mental culture that have been hitherto open to them.

An explanation of the appearance just now of such efforts and convictions must be sought for among those facts of our present social condition which are making the Woman's Question in all its aspects one of the foremost problems of the time. It is obvious enough what some of these facts are, but we should have little confidence in an attempt to enumerate them all, and to estimate exactly their relative importance. But without undertaking to explain fully the movement under discussion, we think there are evident signs that it is a natural and spontaneous outcome of existing social and intellectual conditions, and not the result of artificial stimulus. If this view is correct, it is obvious that the importance of the movement must be judged of rather by what it indicates than by what it is,--by future results that may be hoped for, rather than by successes already achieved. Looked at in this way, it claims the serious attention and support of every one who desires the intellectual advance of the community, in order that the present opportunity may be turned to advantage, and that efficient plans of future action may be founded on the experiments now being tried with more or less of what must necessarily be temporary enthusiasm.

We venture to assume that in this, as in most other cases, the first condition of permanent success is that the object aimed at should be one in which it is worth while to succeed. If both lecturers and students are in earnest in trying to make these lectures really educational and serious, they cannot fail of producing valuable results. But this will require a good deal of determination on both sides. The most obvious, and perhaps the most serious, danger besetting the teachers, is the temptationarising from an unconscious want of respect for their audience-to make their lectures interesting, instead of trying to impart the greatest possible amount of solid instruction. We confess that one or two very attractivelooking programmes that we have seen have suggested the thought, that possibly the lectures they announced might be equally well described as essays, such as constitute the more thoughtful kind of magazine articles; and that, if this were the case, it was not obvious what greater advantage would arise from their author reading them aloud to an assemblage of ladies than would result if the same ladies could be induced to read them to themselves at home.

But, though we have no reason to believe that such a criticism would be really applicable to any of the actual courses, it is none the less desirable that all concerned should be on their guard against the tendency for it to become so. Thorough teaching, and not entertainment, of however high a kind, is what we trust that every lecturer will strive to give, and every student to obtain. And, after all, the spirit and quality of these lectures will depend as much on the students as on the teachers. No doubt a thoroughly earnest teacher may do a good deal towards producing earnest pupils; but, in the long run, the kind of instruction given will be that for which there is a demand. Ladies who intend to join any of the classes now forming will not expect to get any benefit from them, unless they give up for them all other engagements, at least so far as to be able to attend with regularity. If they only go to the lectures when in want of other occupation, they had better not go at all. Moreover, we have not much faith in the educational value, - at any rate for residents in London, $\rightarrow$ of courses in which only one lecture is given in a week. There are few persons who can keep up any vivid interest in a subject which occupies their thoughts for only one hour a week; and we inagine that ladies, who are unwilling to spare the time for two lectures a week on a subject which they wish to study, will scarcely be found among the number.

In conclusion, we may remind our readers of two sets of lectures to ladies which begin this week in London: one of them at the South Kensington Museum, and the other, by Professors of University College, partly at St. George's Hall, Langham Place, and partly at University College. We heartily wish success to them all, and urge all our readers to do what they can to promote it.

\section{GEOLOGY AND AGRICULTURE}

WHEN man penetrated into Western Europe and Britain, he found the country clothed with dense forests interspersed with fresh-water lakes, peat-mosses, and bogs, relieved by few open glades, heaths, or moors. The native rocks could only be seen here and there, in crags and escarpments, sea-cliffs, river-banks, or mountainheights ; whilst herds of wild cattle, deer, and lesser game occupied the country, and afforded food to numerous beasts of prey.

In such a country, at first thinly populated, man could subsist by the chase alone, and a long period elapsed ere he added, first the horned sheep, and then the Bos longifrons, to his earliest domesticated animal, the dog, and thus entered on the pastoral stage of his existence.

The shepherd's life, however, although a great step in advance of that of the hunter, necessitates wandering from one point to another in search of fresh pasturage or water. The early shepherd was a nomad, while agriculture proper necessarily dates from the period of fixed residence; for, even admitting that early man might clear for himself-if not with his axe of stone, at least by the aid of fire-a tract of land suited for the growth of cereals, yet he would hardly toil for even such scanty return as he could gather from his little patch of corn, unless he had some kind of fixed habitation, and a recognised right of occupation.

In Britain the art of agriculture, and indeed of all the arts of civilisation, really commenced with the Roman occupation, but the Saxons and Danes who followed, though doubtless good soldiers, sailors, and fishermen, were scarcely less barbarous than the early Britons, and no advance was made in agricultural pursuits until after the introduction of Christianity, the members of the religious establishments, once so numerous, and into whose hands most of the landed property passed, having done much to improve the cultivation of land. 
While the population was comparatively small, the amount of land under cultivation-was also limited, only the better class of soils in the most fertile districts being chosen for corn, and the remainder used for pasturage or common-land; whilst large tracts of country, capable of producing abundant crops, were left wild, or still covered with woods : but as people congregated in centres of trade, the demand for corn arose and increased. Although, however, the farmer was thus encouraged to attempt the tillage of waste lands hitherto neglected, little improvement is noticeable in the method of farming until the beginning of the present century; for agriculture, like all venerable arts, has been-until very lately-strictly conservative; so much so, indeed, that many of its practices and precepts have come down to us but little altered since the days when Virgil wrote the Georgics.

But this century, so pregnant with change to all our industries, has not permitted agriculture to escape innovation; and notable among the signs of the time was the establishment, in 1838, of the Royal Agricultural Society, under whose auspices much has been done towards the removal of Iong-cherished and old-established prejudices, and the acceptance and adoption of numberless improvements.

The chemist has been, and indeed is still, hard at work for the agriculturist, analysing the soils on his farm, and advising him what artificial remedies to apply to improve their fertility, or to fit them for special crops. He has told him the reason why a rotation of crops is beneficial ; because a green-crop, a root-crop, and a graincrop each take different ingredients from the soil; and thus, by a knowledge of their requirements, he may apply to each that special ingredient-if not already in the land-at the period when it is required by the plant. Nor has Geology neglected to tender her aid to agriculture, by pointing out that there exists a direct relation between the soil of a given area and the subsoil upon which it rests; and that thus, by a knowledge of the geological features of a country, the farmer, in the selection of land, may not only be guided to the most permanently productive soil, but also to that which rests upon a subsoil calculated to enhance rather than deprcciate its value.

Anyone who will take the trouble to examine a geologically coloured map of the British Isles, will see at a glance the general distribution, at (or near) the surface, of all the various geological formations, from the Pliocene and Eocene in the east and south-east, to the Granites and Trap-rocks of the west and north, with the relative superficial extent of each. But let us take a nearer view. In Britain, as in almost every country in the world, and in all latitudes, superficial accumulations of clay, sand, and gravel occur, sometimes forming a mere coating of the rocks beneath, but often of very considerable thickness, and covering large areas. The earlier geologists classed the whole of these deposits under the general name of Diluvium, and attributed their irregular occurrence and wide distribution to the effects of one great and universal deluge. They have, however, of late years, received careful attention from many able geologists, and it is now ascertained that they sometimes contain fossils.

Thus, some are named "pre-glacial," as marking by their animal and vegetable remains a coldly-temperate climate, and comprise marine sands and gravels, the lignite clays, and the forest-bed, with its elephant-remains, which are seen cropping out on the Norfolk coast. Younger than these, and overlying them-in Norfolk at least-come the accumulations of the "glacial" period itself, marked by the Arctic character of its fauna, its iceworn erratic blocks, and its vast deposits of boulder-clay, often 100 feet in thickness, and covering large areas in the eastern, central, and northern counties of England. It presents most anomalous appearances, the fine clay or "till" being unstratified and mostly devoid of fossils, but containing rounded and angular fragments of rock, having one or more of their sides ground down and striated. The laminated beds which accompany the "till" in Norfolk are highly contorted, and much false-bedding and irregularity exists in their mode of deposit. To these succeed the "post-glacial" period, marked by a more temperate climate, and represented by deposits which have been formed since the land assumed its present level, or nearly so ; including lacustrine and river-sediments, turf-moors, ancient forests-sometimes converted into peat-bogs, and now again reclaimed by man; valleysediments, resulting from meteoric causes, and, in fact, all the most modern surface-deposits, including remains of man and his works.

Although what we have already said about the direct connexion between the soil and the sub-soil does relate to the regularly stratified deposits, such as the Chalk, the Oolite, Lias, New Red sandstone, \&c., yet it is found by careful observation that those modern and superficial patches of clays, sands, and gravels scattered over the face of the country far and wide, take such an important part in modifying the general character of the soil, that to the agriculturists of some districts, they actually surpass in interest and importance the more regular geological formations of the country.

When the Geological Survey of Great Britain was first undertaken, more than thirty years. ago, the DirectorGeneral had to consider and decide which would be the most desirable plan to pursue,-whether to show on the geologically-coloured maps these "detrital" or "superficial" deposits, lying upon and concealing the more regularly stratified formations, or only to map the latter; and bearing in mind the fact already stated, that only the most vague notions existed in the minds of the earlier geologists as to the age or origin of these later deposits, and that they were commonly looked upon as the result of the deluge; it is easy to see that there were at that time good grounds for their omission. It can, however, readily be shown that, from an economic point of view, these deposits deserve to be mapped, in the interest of the farmer, with as much accuracy as the older rocks have been for the miner.

The advantages to be derived by the farmer from the mapping of all surface-deposits--irrespective of age or mode of occurrence-are exemplified in the pages of the last number of the Journal of the Royal Agricultural Society, in which the system commenced many years ago by the Council of that Society, and carried out so ably on their behalf by Mr. Joshua Trimmer, of making reports upon the agricultural geology of lands in various districts of England, has been again resumed. In this instance, most of the reports are the result of personal 
inspection of the districts by Mr. H. M. Jenkins, the recently elected Secretary of the Society; who, fresh from his labours as Secretary to the Geological Society of London, has given, in addition to an insight into the methods employed for improving the land, very clear and accurate sketches of the geology of each farm over which he has gone, illustrated in each case by a shaded map, expressing

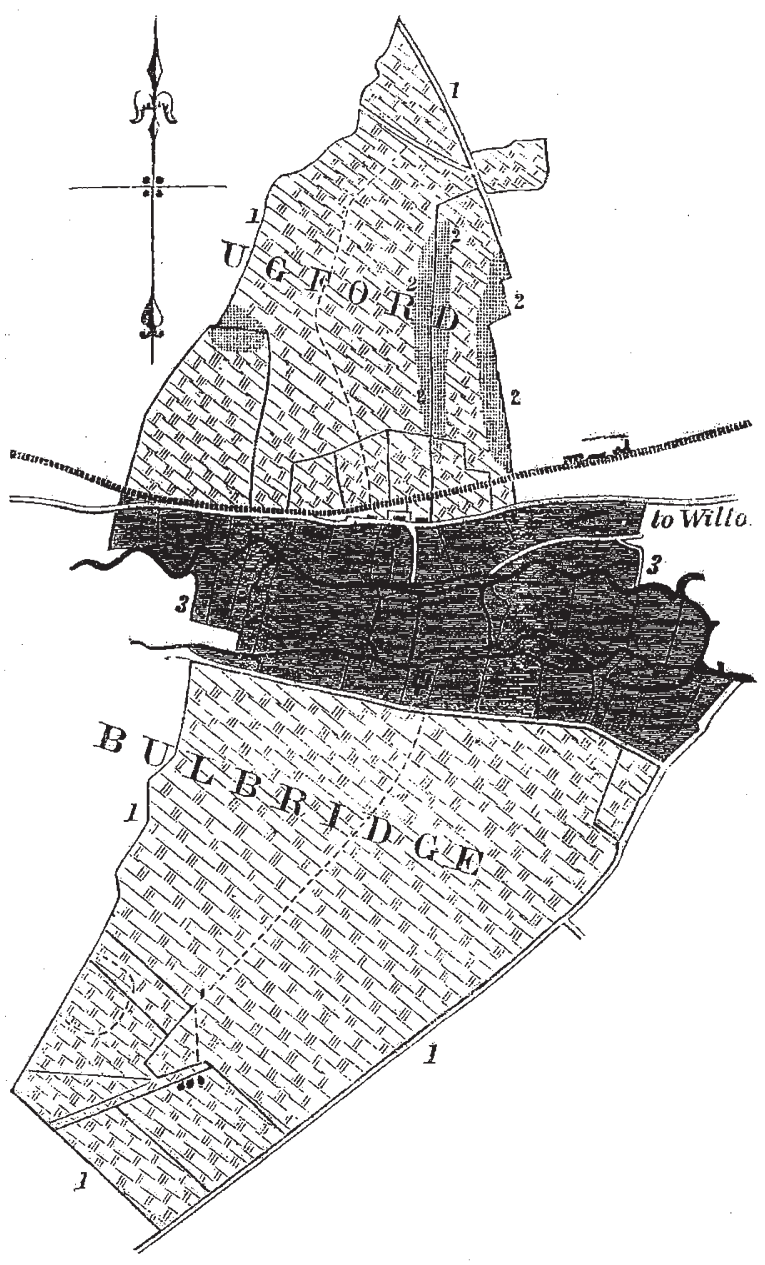

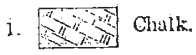

2. Tertiary.

3. Allivium (t'itiet-meädoirs).

Subsorl Map. Scale-Two inches to a mile.

the nature of the subsoil, and its bearing upoin both the lithological nature of the soil, and its retentiveness of moisture-this latter point having a most important bearing upon its fertility.

In illustration of the various conditions under which the surface soil is cultivated, we may refer our readers, first of all, to the recently issued number of the journal referred to. We there find, in an essay on Forest-farming, by Mr. Jenkins, that "the site of the ancient forest of Sherwood furnishes some of the best examples in England of successful farming, under circum- stances of great natural difficulty. The subsoil consists of a sandy conglomerate, and is covered by a very light sandy loam of poor and hungry character. Little is yielded by it alone; and the farmer looks upon it more as a vehicle whereby he can convey fertilising materials to his crops, than as a producer of their natural food." Here we have a natural condition of virgin barrenness, forced into fertility by the most advanced appliances of agricultural science; and from this basis of natural poverty we may diverge, on the one side, into fields which, once naturally fertile, and possessing a rich store of accumulated wealth, have been impoverished, and even denuded, of their wealthy mantle of soil at any rate, by a very recent degradation; and, on the other side, we may find examples where the wealth and fertility of a district are being continually increased by atmospheric causes. Mr. Jenkins gives is instructive examples of both sets of conditions, in one case both occurring on the same farm, viz. at Eastburn in the Yorkshire Wold: on one portion of the farm "the higher ground exhibits a soil gradually increasing in strength and depth as one ascends the hill;" while upon another portion of the farm, the thickness of the soil follows a rule precisely opposite to that just noticed: "instead of the depth and strength of soil increasing with the height, the opposite is now the case. The only essential physical difference in the two cases seems to furnish the explanation of this anomaly, namely, that we now have to deal with a wet valley of very slight slope, the soil on the sides of which consists of the mud (or warp) deposited by the stream in times gone by ; whereas, in the other case, the valleys are dry, and their slopes have been denuded of any alluvial soil which may formerly have covered them, by an agency which has also deepened the valleys and increased the pitch of their sloping sides." All these practical descriptions, the result of actual survey, show clearly that the formation of soils is not always attributable to the same cause; for we have in them clearly indicated three natural processes by which the surface-conditions have been produced-viz. (I) Soil formed from the subsoil immediately beneath; (2) Soil formed by the denudation of soil and subsoil at higher levels; and (3) Surface denuded of soil by degrading influences. The first two processes are formative, while the third is destructive; and thus in this, as in every other portion of nature's economy, we at last learn that antagonism produces equilibrium.

\section{H. WOODWARD}

\section{VEGETABLE PALAEONTOLOGY}

Traite de Paleontologie Végétale. By Prof. Schimper. (Paris, 1869 London: Williams and Norgate.)

I $F$ asked to indicate the most suggestive discoveries in Geological Science that have been made within the last ten years, we should unhesitatingly point to that of the Eozoön,- - to the unfathoming of the mysteries of the floor of the ocean,-and to the unearthing, in high Arctic regions, of forests of Dicotyledonous trees, not merely analogous in size, habit, and conditions of life, but specifically closely allied in structure to the forest trees of middle and southern Europe, Asia, and North America. The first of these discoveries carries 